Assessment Allegories: A Reflective Essay

SHARON MURPHY

York University

Originally presented as an invited address at the Pre-Conference Institute of the LLRC, London, Ontario, May 27, 2005 
Stories are central to human experience (Bruner, 2002), and for language arts researchers, stories are the leitmotiv of what we do. We investigate how we can assist children in reading and understanding stories. We study the composition of stories and other texts. We think about how we can assist children to create their own oral and written stories. We use stories in the form of qualitative research as a vehicle for documenting our investigations in the language arts.

Allegories are a particular kind of story. The word allegory comes from the Greek "allos," which means "other" and "agora," which means a "gathering place" such as a market place. In ancient times when one wanted to speak of something in the market place but was afraid of being punished, that person would intimate or speak indirectly. . . in other words, speak "otherly". As time went by, the two Greek words were combined so that they referred to "the act of speaking about one thing while meaning another."1

In this essay, I am using three stories to speak otherly about assessment in language arts. One story is derived from my own personal experiences, the second from the work of a short story writer, and the third from the work of a novelist. Each of these stories, as do most stories, are full of moments of assessment since assessment is something we do every day. My interest is to take some of these moments and explore them for the insights and relationships they make to the field of education in general and language arts in particular.

\section{"Elusive Illustrations"}

The first story, "Elusive Illustrations," comes out of a serendipitous event that occurred while I was waiting in a physician's waiting room. A mother and her two year-old daughter were passing the time reading one of the children's books in the reception area. The mother opened the book to the beginning of the story. These first two opening pages of the story contained a single illustration spread across two pages (a two-page illustration) and some text on the second of the two pages. The mother read the words of the text, pointed to the main character of a squirrel depicted in the illustration and said, "Look, there's squirrel!" The little girl scanned the pages and then the mother turned the page.

On each of the next two pages there were one-page illustrations - in other words, there was one illustration on one page and a fully separate illustration on the other page, rather than one large illustration covering both pages. The mother asked, "Where's squirrel?" Her daughter happily pointed to the character who, in that instance, was depicted in each of the illustrations and then the mother turned the page. The same character depiction in each one-page illustration occurred for the next two pages and the daughter in anticipation of her mother's query and without any linguistic prompting said, "Squirrel," as she looked at each of these two pages and the mother turned the page.

On the next two pages there were one-page illustrations, but in this instance the main character was depicted in only one of the illustrations. The little girl readily pointed to the character

1 This discussion of the etymology of "allegory" is derived from Etymologically Speaking accessed May 1, 2005 at http://www.westegg.com/etymology. 
depicted in the one illustration, and said "Squirrel," but was clearly puzzled and said, "Where's squirrel?" repeatedly as she pointed in the general direction of the other illustration in which the squirrel was not depicted. The mother understood her daughter's response as a misapprehension that there were two squirrels in the story and referred back to the previous pages in an effort to show her daughter that there was only one squirrel in the story.

This story provokes assessment issues that are central to any consideration of literacy assessment. The first is a basic question whose focus changes depending on the area being assessed. For our purposes, in the context of this story, the question is: "Was this a literacy event?" (Harste, Woodward, \& Burke, 1984). Would this provide evidence of literate behavior? The answer is it depends. It depends on what you count as literacy knowledge, or, to frame it another way, it depends on what your literacy values are.

Our literacy values can be taken from vastly divergent places such as: our own egocentric perspectives of how we became literate; folk practices, as illustrated in Feitelson's (1988) commentary on spelling as a method for learning to read): the residues of a once "proven" but now discredited study such as the Morphett and Washburn (1931/1983) study which gave us the term reading readiness; contemporary research such as Ferreiro and Teberosky's (1982) insights about the syllabic period or Charles Read's (1975) work on the early development of spelling; or reading theories such as those of Goodman (1994) or Stanovich (1986). If your values count literacy events as those which involve only print, and do not account for book knowledge, then the little girl might be said to be pretend reading or playing with books but would not be engaging in a literate act. This point is tremendously important when thinking about literacy assessment since we so often adopt terms like reliability, or face or content validity to talk about assessment, but we neglect to forefront the fact that, like a narrative text, each assessment move is a move that sets a trajectory. . . it makes assumptions about the exercise of assessment that will impact on what is considered valid or reliable. In short, one person's face or content validity characteristics are another person's exclusionary criteria for thinking about what counts as literacy.

I believe that this girl's detour into world of picture book illustrations indicates how she is finding the ambiguities inherent in her world and making hypotheses about the socio-cultural conventions underlying the relationship of illustrations, stories and characters. Those of us with this view often colour our descriptions with adjectives such as "rich," "complex," "multifaceted", and "textured." In so doing, we imply that those who hold values other than ours have a simple, single faceted, and un-nuanced view of literacy. And as much as I subscribe to the view of this girl as demonstrating much about literacy, I want to argue, for the moment, that these views may be as enabling as they are disabling. This is what values do. . . they predispose us to view the world in particular ways, to make judgments (or assessments) based on those views, and to advance knowledge in so doing. Our values may help us see certain things but they may obscure or even blind us to others. Our challenge is to remain open to new possibilities.

I want to illustrate this idea of new possibilities in two examples, one drawn from my own personal experience and the other from the research literature. I engage in an exercise with my undergraduate language arts classes which other language arts teacher educators probably undertake as well. I ask my students to think about young children and their intentions in writing. The students I teach would be about two-thirds of the way through a 36 hour course on general language arts 
when I talk to them about assessing children's writing. I place on an overhead projector a short story written by a first grader, such as the following one found in Eckhoff (1984, p. 111):

A woman bot some tomatoes

Hsea is happy

Hsea is old

Hsea is at the macit
[A woman bought some tomatoes.]

[She is happy.]

[She is old.]

[She is at the market.]

I ask them how they might evaluate the piece of writing and the typical responses I get (once they get over the obvious matters of form) are that the story has a beginning, a middle and an end. And indeed, this is one of the values perpetuated in some of the material I have given them to read. However, I go on to challenge them to think about the piece as a literary work, a piece full of authorial choices, a piece in which the author made conscious decisions to include a word here or to omit or include certain content, decisions which may have created suspense, led the reader towards a certain narrative trajectory and make for a somewhat satisfying, though short, narrative. As I begin my efforts, the reaction of students ranges from tepidness to surprise to incredulity because they are being asked to view a child's work as a literary accomplishment. ${ }^{2}$ I say things to them like, "Look at that opening line and think about the decisions the author had to make. The woman is front and centre of this story. Your curiosity is aroused as a reader. Who is this woman? What is she doing? Will she continue to be central to the text? What kind of woman is she?" And we aren't even at the tomatoes part yet.

Even though this story is considered to be a less literary story (in Eckhoff's [1984] comparative analysis of the writing of children who read basals of differing literary qualities), it is important to see the moves the author makes. The author paints a visual picture. The author locates the woman not in a store, nor in a shop, but in a market. Might this wording have anything to do with the age of the woman? I think you get the picture of how I press questions about the text. In any event, by the time I finish, I usually feel that I have convinced most that noting that a story has a beginning, middle and an end is not a sufficient way to assess the literacy knowledge of young writers. Indeed, it is somewhat demeaning. As we all know, young writers are up to much more than creating a beginning, a middle, and an end when they put pen to paper even for these very short texts. To return to the physician's office picture book illustrations story, for a moment, the mother there assumed that her child was working from and with knowledge in making comments about the characters in the illustrations. Her response illustrates that it is not only values about what counts as literacy that are at work in any assessment, but also what we believe about what children know and intend (which results in particular "readings" of their efforts to interpret their world in writing).

While I like to think that my class opens up new interpretive possibilities for my students, I

2 A dramatic example of the way in which children's work is not valued is found in Fineberg's (1997) work in which children's artworks are placed along side nearly identical works by adult artists. 
want to reiterate the point that language arts researchers must also be open to new perspectives, frames of reference, and disciplines to open up the conversation about what counts as a literacy event, how literacy events have significance, and what we might make of that significance in thinking about literacy assessment. There is much research, if taken up by numbers of people in literacy education, could have significant consequences for views of literacy education and literacy assessment. The work of Rhian Jones (1996) is one example. Even though her research is nearly a decade old, I find that Jones' (1996) work is not referenced much in the literacy literature. Yet, her work is one that I would put in the same class as Yetta Goodman and Bess Altwerger's (1981) environmental print work, or Emilia Ferreiro and Anna Teberosky's (1982) studies of literacy before schooling, or Ken Goodman's (1969) work on miscue analysis. In other words, it casts anew aspects of literacy knowledge that hitherto fore had been unnoticed or interpreted quite differently.

Jones (1996) draws on linguistics, psychology, literary theory and psychoanalysis to examine the experience of reading during the first several years of life. Jones' work is not concerned explicitly with teaching nor is it concerned with assessment. Rather her interest is to uncover the experience of reading. Many literacy researchers would find that Jones' work (on picture book reading and word meaning or event interpretation, or her work on the emergence of the narrative) fills out the continuum of our descriptions of literacy development. What is novel for me, however, is when Jones draws on the psychoanalytical perspective of Winnicott to consider questions of attachment and reading. Specifically, Jones considers how the residues of children's use of pictures and books as transitional objects in very early years are manifested in later years (and, I would say, differentially impact children's relationship with texts). Recall for a minute the transitional objects we most closely associate with early childhood years... the tattered blanket that is so frayed that one fears it will disintegrate. . the teddy bear so used that its polyester fur is worn bare with the occasional tufts reminding one of what has gone before. These objects are the ones that children control, love and hate, and that only they have the authority to change. Consider that Jones found that for very young children pictures and books can be transitional objects. Consider the loss that children would feel as a result of their separation from their transitional object texts and imagine the impact that such attachments would have, not just for the psychological development of the child, but for their views of texts. Jones observed that the personal attitudes manifested in the first two years of life were evident in children's interactions with texts into their sixth and seventh years of life (which was the scope of her study) and she speculated that they perhaps had influence beyond this period.

This detour into the world of books as transitional objects may seem far afield from literacy assessment, but it isn't. In fact, it again goes back to questions of values and what assessments see and don't see. As I have argued elsewhere, assessments "find" the literacies they recognize and they fail to find the ones they don't (Murphy, 2003). Most of our assessment tools, even the innovative ones, don't delve anywhere near psychical attachment, yet, if we were all pushed, I believe that no one would deny that without an attachment to the act of reading, neither children nor adults will ever learn how to read. And here I am talking about something deeper than what is traditionally defined as motivation, but is something that can occur at a deep emotional level and perhaps at a visceral level as well. It is something that we are a little afraid of in the field of literacy education as we don't indulge much in discussions of pleasure and pain in relation to literacy engagement, but we are 
more inclined to think of the more seemingly trite characterizations like "fun."

How might we assess these complex notions? I confess I don't know. But I do know that until we first recognize them and incorporate them into our literacy values, there is little hope that we will think of them when we are asked to think about literacy assessment. I also want to add that I am not advocating for CIA-like investigations into literacy. Rather, a gesture towards the emotional investments one has in literacy might go towards deepening our insights into how children are situated as literate persons.

My next stories are ones you may have heard before either because you have read them in their original sources or because you have read of them. They are both, in some ways, stories of the loss that is begotten by assessment.

\section{“Looking for Johnny"}

My second allegory is, in its full version, is based on the short story called "Looking for Johnny" found in the short story collection The Safety of Objects by the writer A. M. Homes (2001). In this story, Erol, a boy of nine, is abducted from a basketball court. Erol is lured to go with someone who tells him that his mother had sent this person to pick him up. Even though the stranger, calls Erol by the name Johnny, he goes off with this stranger who he later figures out is a kidnapper. The kidnapper is an unusual sort as imagined kidnappers go. He occasionally administers a drug to Erol to make him sleep but, apart from that, engages in a series of relatively benign activities. . . activities that seem to represent an idylicness. . . activities such as making Rice Krispie Squares, ... watching T.V., ... going fishing. Erol's reactions to these things is muted and clumsy, and perhaps not what the kidnapper imagined (Erol is not fussy about baiting hooks, for instance). The kidnapper decides to return Erol because he is not Johnny. When Erol is deposited close to his home, he is noticed by his mentally handicapped sister whose mispronunciation of his name as "error" resounds in Erol's head as he runs away from her and his home to other yards until he is exhausted.

What do we make of this story as an assessment allegory? Consider for a moment the kidnapper's criteria of what constitutes a "good enough" Johnny. It is not unlike the question of what constitutes a good enough reader or good enough writer, but the allegorical nature of the story goes beyond the quality of the literacy to the qualities of the person. Imagine the kidnapper's parameters; he may have wanted a "Leave It to Beaver"-like enthusiasm in his abductee. Maybe the kidnapping was about re-enacting events related to a loss in the kidnapper's life, or perhaps the kidnapper was re-enacting an imagined sense of middle America. For Erol, at least, fortune smiled ironically because rejection meant escape.

Erol's situation highlights the fact that not only are literacy assessments marked by the values one has about literacy, but they are also marked by socio-cultural values and assumptions contained within the texts that are read or produced. These values make reading and writing possible and impossible. We know from reading research on the effects of background knowledge, that background knowledge can facilitate reading achievement (e.g., Johnston, 1984; Langer, 1984).

We also know from schema theory work (e.g., Anderson, 1985) about the effects that preconceptions have on the possible ways a text can be read. And, we know from studies of the 
social practices of literacy that children can be apprenticed to the reading of texts in particular ways (e.g., Fishman, 1988; Heath, 1983). Lay on top of this the effects of culture (such as that reported in the classic work of Sir Fredrick Bartlett [1932/1961], or class and culture as reported in more recent work by Purcell-Gates [1995]), and it becomes clear that the wonder of reading is the fact that we can ever agree on any interpretations we make of text. If nothing else, such work suggests the tentativeness of textual interpretation and the need for an idea of reading that incorporates the defensibilities rather than the definitiveness of interpretations.

Even though assessments informed by progressive literacy values are probably more likely to consider the dynamics of background, culture and class as represented in texts and readers or writers, it is also possible that these assessments may need reminding of the dynamics of sociocultural values. Why, for example, when gender and literacy come into play, are so many of the worries located in boys' literacy? How does one make sense of these worries in relation to the established literary canon which has been dominated by men? Here's a different example: How can we get beyond ourselves in the analysis and interpretation of miscues? How can we come to terms with differences not only in text content, but in text structure as motivated by cultural differences as found in the work of people like Sarah Michaels (1985)? How do the possibilities we make available to children in classrooms define the kinds of literacies we find and don't find in our assessments?

If we return to Erol and Johnny again, the most painful point in the story is not the event of the kidnapping, nor does it seem to occur in the repeated missed connections between Erol and his captor. Rather, it is the point at which Erol returns home to be greeted by his mentally handicapped sister who mistakenly pronounces his name as error, but whose mistake resonates through the whole event of the kidnapping. Something that we imagine should have placed Erol in the position of victim is now announced as a mistake embodied in Erol who, through his lack of shared experience with the kidnapper, has been made to feel inadequate, "less than," and diminished. I wonder how many children, who, only by virtue of their failure to hold in common the same cultural experiences of their assessors or whose different experiences go unrecognized, share feelings like Erol's.

\section{"Bee Season"}

My last story is found in its full version in Myla Goldberg's (2000) novel, Bee Season. In this novel, the central character, Eliza, is good at spelling. She comes about her "goodness" not by the anticipated means of extra studying but, in some ways, could be thought to be a little indifferent to spelling and to studying in general. To quote Goldberg (2000), for Eliza, "studying has always been a chore on the level of dish-washing and room-cleaning, approached with the same sense of distraction and reluctance. Eliza fears that studying will leech her of spelling enthusiasm” (p. 41).

And then the unthinkable happens. Eliza places first in her class spelling bee and from there arises the vision of a succession of spelling competitions potentially culminating in the National Bee. From that moment of the winning, of spelling correctly the word "weird" (another irony), Eliza's world shifts. On the one hand we see Eliza who, in a seeming echo of Vygotsky's comments about play, says of herself, "This is what it is like to be tall." But we also see an Eliza who is 
viewed differently by those around her. Her principal announces her name on the PA (instead of seeing her as the child who didn't try out for the gifted class). Her father sees her as someone in need of rabbinical guidance with respect to spelling, her mother sees (and yet doesn't see) the realizability of her own desires in Eliza. Her brother now sees a competitor. Eliza finds herself confronted with the struggle to be who she was. At first, "she reluctantly maintains her after-school schedule of television reruns, pretends not to notice her father's raised eyebrows at the sight of her in her regular chair, nary a spelling list or dictionary in sight" (Goldberg, 2000, p. 43). But as the novel progresses, things change as Eliza becomes a student of words and worlds.

This brief encapsulation does not do justice to Goldberg's work, but the glimpse into the story offered much in terms of assessment. I want to address three issues that arise from Bee Season which arise out of a concern for what is called consequential validity (Messick, 1988). Consequential validity involves judging "the intended and unintended social consequences of test interpretation and use" (p. 39). The issues I am selecting to address in Goldberg's novel are about the consequences of assessments. . . how they make and unmake people, how knowledge can become an all or nothing game, and how assessments can have an effect on the teaching and learning environments that follow in their wake. These issues are all interrelated with each other and with the themes that I introduced in the previous allegories, but I will try and deal with each separately.

In Goldberg's novel, we are confronted with the consequences of a less talked about aspect of assessment. . . and that is the consequences of a highly positive assessment. Eliza becomes someone else because of assessment. Words like "winner" or "champion" work in the service of constructing the identities of the characters in the novel. However, as my synopsis of the story illustrates, it is not just Eliza's identity that is constructed as a consequence of her seeming victory over words, but the identities of those around her shift in relation to hers. Think about that for a minute. . . with the conventional spelling of a single word comes a sea-change for Eliza and those around her. That truly is weird!

In essence, she is created anew or, as the philosopher Ian Hacking (1990) might put it, she has been "made up." Now Hacking (1990) is talking about how numbers make up people, an argument with which we are all too familiar. We have heard it in education texts like Denny Taylor's (1993) From the Child's Point of View; we have heard it in anthropological studies like F.A. Hansen's (1993) study of how testing permeates so many facets of culture in the United States - not just education; and, we have heard it in humanities studies such as Mary Poovey's (1998) study of the history of bookkeeping. Arguments about the arbitrariness of numerical indices as representations of literacy or other knowledge areas are even more greatly amplified by the current debates about the No Child Left Behind federal legislation (see for example,Meier \& Wood, 2004). And, some "alternative" assessments sometimes position themselves in a passionate smugness over the fact that they use words rather than numbers to report out the results of assessments, but words carry with them their own sets of problems.

In the context of Goldberg's novel, words like "winner" or "champion" can be traced back to numbers because these words have an "all or nothing" sense about them. However, in other contexts, words, like numbers, are vehicles of more elaborated meaning, whether that meaning is the language of portfolio assessments, miscue analysis, developmental reading assessment or something else. The language used in assessments is as important, if not more important, than the numbers used in some assessments. To take miscue analysis as an example, many aspects of the language 
developed by Ken Goodman (1969) with respect to miscue analysis demonstrated a carefully positioned response to issues around word choices in assessments - miscues as opposed to errors, observed and expected responses as opposed to correct and incorrect responses and so on. In fact, miscue analysis can be distinguished from most other assessments, including the methods of Reading Recovery (Clay, 1972), because of the insistence of using a particular positioning of the reader as knowledgeable rather than a positioning of the reader as an accidental tourist traveling through the land of print. Oral reading analysis approaches that reduce down to a correct/incorrect analysis, work on a knowledge/ignorance dichotomy. That is, you either know or you don't know the word.

If children's efforts were treated as the work of knowledgeable persons, how might our interpretations differ from when we assume their work demonstrated ignorance? Charles Read (1975) began to get at this idea when he assumed that children's early spellings were based on knowledge of the relationship of their own articulatory systems and conventions of graphic representation in English. To go back to the earlier example of my practice in my undergraduate class with respect to very young children's writing. . . once we acknowledge that children are people who, like us, are not so happy being made fools of, or who do not want to demonstrate some lack that they have, but instead make purposeful and informed choices in their interactions, we are forced to find new language possibilities to position them and their knowledge. One example of this, in the area of early writing is found in Gunther Kress's (1997) Before Writing; in this text he interprets children's images from the perspective of their deliberate symbolic engagement with the world around them. He martials a set of evidence to illustrate that just because children do not represent the world according to the conventions that exist in the larger society, does not mean that their representations are without systematic attempts at meaningfully organizing the graphic system.

The second theme that I see arising from Bee Season is, to some extent, intertwined with the first. This theme is the "all or nothingness" of some assessments. In Goldberg's novel, the consequences of achieving a conventional spelling, or perhaps, a series of conventional spellings within and across competitions, is always an all or none effort every time a word is spelled. The word is either right or wrong. No credit is given for partial knowledge, and as a result, no deep insights about a student's learning can be achieved. Think about it. The word "want" spelled as "Xxxxx" essentially is accorded the same credit as if it had been spelled as "went," correct with the exception of a single letter. Granted that in education, as in life, there may be occasions in spelling knowledge which demand a precision that is worth the consequence of having partial knowledge discounted (spelling "fir" instead of "fire" as a warning, for instance). But given that we are in the business of education, I am inclined to argue that, in most typical education contexts, there is something wrong with an assessment world in which partial knowledge is treated as detritus or, as in the case of multiple choice assessments, treated as a means to trick one into selecting the incorrect response.

If assessments devalue the very thing we are trying to achieve, which is knowledge, how can they be something upon which to build? It is true that in education, we sometimes talk about building on children's strengths, but this demand can lead us into pop psychology fixes and can result in children being given labels like "visual learner" or "right brained." A more interesting challenge, I believe, would be to move away from the idea of strengths and to switch to the idea of 
children's knowledge.

In Bee Season, Eliza eventually comes to her own decision about the context in which conventional spelling is important, as well as the consequences she is and is not willing to bear by being a great speller. Her decision comes from a position of extraordinary strength and knowledge; yet, one is left feeling that others around her continue to be ignorant. This ignorance of the consequences relates to the last theme I want to address from Goldberg's Bee Season, and that theme is the effects that assessments can have on teaching and learning. For Eliza, the desire to be herself was her starting point. However. . the seduction of winning, of being noticed, sets in play other events including her father's decision to use ancient texts and the study of the Kaballah as a route to the ultimate goal of winning the National Spelling Bee. Spelling takes over not only the life of Eliza, but it insinuates itself into her family in complicated and nefarious ways.

The idea that assessment can narrow one's teaching and learning engagements is not a new one. Researchers such as, Hill and Larsen (2000) have provided stunning analysis and critique of standardized reading tests that leave one wondering why anyone would make any decision based on such tests. Others, myself included, have warned for instance, that standardized tests narrow curriculum (Murphy, Shannon, Johnston, \& Hansen, 1998). However, recent research in the areas of mathematics and science education has revealed that the effects of large scale high stakes tests are more complex than first thought.

In a multi-year, site, and method study, Firestone, Schorr, and Monfils (2004) and their colleagues examined the relationship between test preparation and a host of variables. They describe the results of their investigations in a book entitled, The Ambiguity of Teaching to the Test: Standards, Assessment, and Educational Reform. Drawing on observation and interview data, Monfils, Firestone, Hicks, Martinez, Schorr, and Camilli (2004) discovered that the responses that teachers make to high stakes testing situations are quite diverse. They report that, paradoxically, teachers intensify conventional practices while demonstrating an interest in reform. The most extreme version of this response occurs in poor districts where teachers can be found to be

changing content and adopting instructional strategies consistent with some reform strategies... [and] increasing the use of manipulatives and open-ended items [but] increasing their decontextualized test preparation though the use of commercial test prep materials, teaching test-besting skills, or holding practice sessions. (Monfils et al., 2004, p 61)

Firestone, Montfils, et al. (2004) report that the publication of test scores results in what they refer to as "a diffuse sense of dread and pressure to improve" (p. 64). For teachers not high on the self-efficacy scale, this leads to the reinforcement of conventional practices and the use of short term strategies to raise test scores. Even more worrisome is the pattern that the teachers most likely to engage in these curricular narrowing practices of teaching to the test are those in poor districts while teachers in affluent districts tend to work with more of an enriched curricular focus.

The work of Firestone and his colleagues certainly appears to put in question the efficacy of teaching to the test, broadly constituted but it also raises questions about the differential treatment of students across socio-economic class structures. And, as a result, it appears to argue for a type of education that is not as much about passing tests as it is about learning how to be, think, and contribute to the world. Some, like the psychologist Robert Sternberg (2003) have begun to move in broader directions in their research. For instance, Sternberg (2003) suggests that intelligence is about more that analytic and quantitative abilities, but must also take into account creative abilities (ways 
of going beyond the given to create the new) and wisdom (the ability to act with prudence). Sternberg (2003) is busy building an intelligence test that might account for these factors. It seems to me that even some of our "authentic" assessments in literacy education have a tendency to stop at the creativity side of things leaving considerable room for thinking about how wisdom is demonstrated and indeed cultivated. What does it mean to use the language arts wisely? To return to Goldberg's novel, it is somewhat ironic that Eliza, who makes as decision and acts in a manner that I would call wise, does so in response to a series of events that might have cascaded anyone else into responding in narrow, and unwise ways.

\section{Final Thoughts}

I'd like to conclude these assessment allegories with a metaphor that comes out of my escapist reading of mystery novels. In the mystery novel Stone Dust by Jason Scott (1995), the front matter makes reference to the building of "flagstone terraces" and I wondered what assessments might be like if we in the field of assessment thought about our work more like that of the mason building the garden terrace. The definition of stone dust goes like this,

Stone dust makes for a livelier bed for a flagstone terrace than does concrete. It's more forgiving: There's nothing rigid to crack; and on barefoot days it lets the cold ground swallow the heat of the sun. You'd best be sure of your mason though. Wide joints inspire weeds (Scott, 1995, front matter).

We need to build assessments that aren't rigid, but that are inherently flexible to meet with changing environmental contexts. Yet, we need to recognize the values that are the bedrock of all assessments, and the differences that exist in rock to rock, so to speak. And finally, we need to realize that our best assessments come from the best in our world. . they are carefully chosen, they interact with other stones to create the wholeness of the path, and their "pathedness" sets a particular trajectory that can be defining in terms of where one ends up. Concoctions like concrete can be poor replacements for flagstone, such concoctions really don't have staying power, yet, if one trips over them and their brittleness is revealed, a lot of damage can be unleashed. Here's to flagstone! 


\section{References}

Anderson, R. (1985). Role of the reader's schema in comprehension, learning and memory. In H. Singer \& R. B. Ruddell (Eds.), Theoretical models and processes of reading ( $\left.3^{\text {rd }} \mathrm{ed}.\right)$. (pp. 372-384). Newark, DE: International Reading Association.

Bartlett, F. (1961) . Remembering: A study in experimental and social psychology. Cambridge: The University Press. (Original work published1932).

Bruner, J. (2002). Making stories: Law, literature, life. New York: Farrar, Strauss and Giroux.

Clay, M. (1972). The early detection of reading difficulties. Exeter, NH: Heinemann.

Eckhoff, B. (1984). How reading affects children's writing. In J. M. Jensen (Ed.), Composing and comprehending (pp. 105-114). Urbana, IL: National Council of Teachers of English.

Etymologically Speaking. Retrieved May 1, 2005, from http://www.westegg.com/etymology.

Feitelson, D. (1988). Facts and fads in beginning reading: A cross-language perspective. Norwood, NJ: Ablex.

Ferreiro, E., \& Teberosky, A. (1982). Literacy before schooling (K. Goodman, Trans.). Portsmouth, NH: Heinemann.

Fineberg, J. (1997) . Children's art and the modern artist. Princeton: Princeton University Press.

Firestone, W. A., Monfils, L. F., Schorr, R.Y., Hicks, J.E., \& Martinez, M.C. (2004). Pressure and support. In W. A. Firestone, R.Y. Schorr, \& L.F. Monfils (Eds.), The ambiguity of teaching to the test: Standards, assessment and educational reform (pp. 63-89). Mahwah, NJ: Erlbaum.

Firestone, W. A., Schorr, R. Y., \& Monfils, L. F. (2004). The ambiguity of teaching to the test: Standards, assessment and educational reform. Mahwah, NJ: Erlbaum.

Fishman, A. (1988). Amish literacy: What and how it means. Portsmouth, NH: Heinemann.

Gentry, R. (1987). Spel-- is a four-letter word. Portsmouth, NH: Heinemann.

Goldberg, M. (2000). Bee season. New York: Anchor Books.

Goodman, K. (1969). Analysis of oral reading miscues: Applied psycholinguistics. Reading Research Quarterly, 5, 9-30. 
Goodman, K. S. (1994). Reading, writing, and written texts: A transactional sociopsycholinguistic view. In R. B. Ruddell , M. R. Ruddell, \& H. Singer (Eds.), Theoretical models and processes of reading ( $4^{\text {th }}$ ed.). (pp. 813-840). Newark, DE: International Reading Association.

Goodman, Y. M., \& Altwerger, B. (1981). Print awareness in pre-school children. A working paper. A study of the development of literacy in preschool children. Occasional Paper No. 4. Tucson, AZ: Program in Language and Literacy, University of Arizona.

Hacking, I. (1990). The taming of chance. Cambridge: Cambridge University Press.

Hansen, F. A. (1993). Testing testing: Social consequences of the examined life. Berkeley: University of California.

Harste, J., Woodward, V., \& Burke, C. (1984). Language stories and literacy lessons. Portsmouth, NH: Heinemann.

Heath, S. B. (1983). Ways with words: Language, life, and work in communities and classrooms. Cambridge: Cambridge Universtty Press

Hill, C., \& Larsen, E. (2000). Children and reading tests. Advances in discourse processes Vol $L X V$. Stamford, CT: Ablex.

Homes, A. M. (2001). The safety of objects. New York: Perennial-Harper Collins.

Johnston, P. H. (1984). Prior knowledge and reading comprehension. Reading Research Quarterly, 19, 219-239.

Jones, R. (1996). Emerging patterns of literacy: A multidisciplinary perspective. New York: Routledge.

Kress, G. (1997). Rethinking the paths to literacy. New York: Routledge.

Langer, J. A. (1984). Examining background knowledge and text comprehension. Reading Research Quarterly, 19(4), 468-481.

Meier, D., \& Wood, G. (Eds.)(2004). Many children left behind: How the No Child Left Behind Act is damaging our children and our schools. Boston: Beacon Press.

Messick, S. (1988). The once and future issues of validity: Assessing the meaning and consequences of measurement. In H. Wainer \& H. I Braun (Eds.), Test validity (pp. 33- 
Language \& Literacy: A Canadian E-Journal

45). Hillsdale, NJ: Erlbaum.

Michaels, S. (1985). Hearing the connections in children's oral and written discourse. Journal of Education, 167(1), 36-56.

Monfils, L.F., Firestone, W.A., Hicks, J.E., Martinez, M.C., Schorr, R.Y., \& Camilli, G. (2004). Teaching to the test. In W. A. Firestone, R.Y. Schorr, \& L.F. Monfils (Eds.), The ambiguity of teaching to the test: Standards, assessment and educational reform (pp. 6389). Mahwah, NJ: Erlbaum.

Morphett, M. V., \& Washburn, C. (1983/1931). When should children begin to read? In L.M. Gentile, M. L. Kamil, \& J.S. Blanchard (Eds.), Reading research revisited (pp. 162-169). Toronto: Merrill. (Original work published 1931)

Murphy, S. (1999). The validity and reliability of miscue analysis. In A. Marek \& C. Edelsky (Eds.), Reflections and connections: Essays on the influence of Kenneth S. Goodman (pp. 95-122). New York: Hampden Press.

Murphy, S. (2003). Finding literacy: A review of the research on literacy assessment in early School Journal, 31:496. Washburn childhood education. In N. Hall, J. Larson, \& J. Marsh (Eds.), Handbook of early childhood literacy (pp. 369-378). London: Sage.

Murphy, S., Shannon, P., Johnston, P., \& Hansen, J. (1998). Fragile evidence: A critique of reading assessment. Mahwah: Erlbaum.

Poovey, M. (1998). A history of the modern fact: Problems of knowledge in the sciences of wealth and society. Chicago: University of Chicago Press.

Purcell-Gates, V. (1995). Other people's words: The cycle of low literacy. Cambridge: Harvard University Press.

Read, C. (1975). Children's categorization of speech sounds in English (Research report No. 17). Urbana, Il: National Council of Teachers of English.

Scott, J. (1995). Stone dust. New York: Penguin.

Stanovich, K. E. (1986). Matthew effects in reading: Some consequences of individual differences in the acquisition of literacy. Reading Research Quarterly, 21, 360-407.

Sternberg, R. J. (2003). Wisdom, intelligence, and creativity synthesized. Cambridge: Cambridge University Press.

Taylor, D. (1993). From the child's point of view. Portsmouth, NH: Heinemann. 
Assessment Allegories SHARON MURPHY 